\title{
ANALISIS TAX PLANNING UNTUK EFISIENSI PAJAK PENGHASILAN BADAN (STUDI PADA PT ABDYA GASINDO)
}

\author{
Sumardi Adiman ${ }^{1}$, Miftha Rizkina ${ }^{2}$ \\ ${ }^{1,2}$ Fakultas Sosial Sains Universitas Pembangunan Panca Budi \\ ${ }^{1}$ sumardi.adiman@gmail.com, ${ }^{2}$ rizkina_miftha@ymail.com
}

\begin{abstract}
The purpose of this paper is to find out whether the application of tax planning carried out by PT. Abdya Gasindo can streamline corporate income tax. The writing method used is descriptive method that is the method that collects, collects the data obtained then is interpreted and analyzed so that it is able to provide complete information for problem solvers encountered. The results of this study are expected to provide information and input on Abdya Gasindo so that the company can carry out tax planning as an effort to efficiently pay taxes to achieve maximum profits, but still within the framework of tax regulations. The conclusion of this study is the application of tax planning conducted by PT. Abdya Gasindo can make efficient the tax burden owed.
\end{abstract}

\section{Keywords: Tax Planning, Corporate Income Tax, Efficiency}

\section{PENDAHULUAN}

Dalam sebuah perusahaan menginginkan usahanya berjalan dengan lancar, baik dalam upaya menghasilkan barang dan jasa yang di produksinya serta memenuhi kewajiban perusahaan tersebut sehingga dapat mengoptimalkan laba. Dimana dengan menghasilkan laba perusahaan dapat mempertahankan pertumbuhan perusahaannya sehingga dapat bersaing dengan perusahaan lain, karena laba tersebut dapat ditanam kembali dan digunakan untuk mempertahankan atau meningkatkan kinerja perusahaan. Namun di samping itu perusahaan juga mempuyai beban yang dapat mengurangi laba dimana salah satunya adalah beban pajak.

Pajak adalah iuran kepada negara (yang dapat dipaksakan) yang terutang oleh yang wajib membayarnya menurut peraturan, dengan tidak mendapat prestasi kembali yang langsung dapat ditunjuk dan yang gunanya adalah untuk membiayai pengeluaran-pengeluaran umum berhubungan dengan tugas Negara untuk menyelenggarakan pemerintah (Brotodiharjo dalam gunadi 2002:2)

Dari pemahaman pajak diatas dapat kita simpulkan bahwa pajak adalah kewajiban yang bersifat memaksa dan terdapat peraturan peraturan yang mengikatnya dimana setiap peraturan pasti ada sanksi di dalamnya seperti sanksi administrasi yang merupakan pemborosan sumber daya.

Oleh karena itu perlu adanya pengelolaan kewajiban perpajakan secara baik dan benar sehingga dapat menghindari adanya pemborosan sumber daya perusahaan sebagai akibat dari pengenaan tersebut. Untuk menekan pemborosan pajak dalam pemenuhan kewajiban perpajakan tersebut, salah satu cara yang dapat dilakukan perusahaan adalah dengan perencanaan pajak.

Perencanaan pajak adalah upaya pemenuhan kewajiban, pengkoordinasian dan pengawasan mengenai perpajakan, sehingga beban yang harus ditanggung perusahaan dapat diminimalkan guna memperoleh laba dan likuiditas yang diharapkan, tanpa harus melanggar undang- 
undang yang berlaku. Upaya meminimalisasi pajak tersebut sering disebut dengan tax planning.

Tax planning adalah suatu kapasitas yang dimiliki oleh wajib pajak (WP) untuk menyusun aktivitas keuangan guna mendapat pengeluaran (beban) pajak yang minimal. Secara teoritis tax planning dikenal sebagai effective tax planning, yaitu seorang wajib pajak berusaha mendapat penghematan pajak(tax saving) melalui prosedur penghindaran pajak (tax avoidance) secara sistematis sesuai ketentuan UU Perpajakan (Hoffman, 1961).

Jadi tax planning adalah upaya untuk meminimumkan kewajiban pajak dimana dapat ditempuh dengan cara mengambil keuntungan dari ketentuan mengenai pengecualian dan pemotongan atau pengurangan yang diperkenankan

Tujuan tax planning bukanlah untuk menghindari pembayaran pajak, tetapi merancang atau mengatur agar pajak yang dibayarkan tidak lebih dari yang seharusnya. Sehingga dapat kita ketahui tujuan pokok tax planning adalah untuk mengurangi jumlah atau total pajak yang harus di bayarkan oleh wajib pajak yang merupakan tindakan legal karena penghematan pajak hanya dilakukan dengan memanfaatkan hal-hal yang diatur oleh undang-undang sehingga menjadi langkah yang tepat dalam mengefisiensi pembayaran beban pajak

Dimana PT Abdya Gasindo dalam melakukan tax planning dengan mencari peluang dengan cara meningkatkan biaya yang yang dapat dikurangkan pada beban pajak sesuai dengan UU No. 36 tahun 2008 tentang pajak penghasilan.

Salah satu biaya yang dapat mengurangi beban pajak sesuai dengan ketentuan UU No. 36 tahun 2008 yaitu dengan memberikan pelatihan atau pendidikan dan pengembangan SDM. Dimana PT Abdya Gasindo dapat menurunkan total pajak penghasilanya serta dapat meningkatkan kualitas kerja karyawan dimasa akan datang dan lebih mampu bersaing dengan perusahaan lainya.

\section{Rumusan Masalah.}

Berdasarkan latar belakang masalah yang telah diuraikan sebelumnya, maka rumusan masalah dalam penelitian ini adalah bagaimana Penerapan Tax Planning dapat mengefisiensi pajak penghasilan badan pada PT Abdya Gasindo?

\section{Tujuan Penelitian.}

Berdasarkan rumusan masalah diatas, maka tujuan penelitian ini adalah Untuk mengetahui Penerapan Tax Planning dapat mengefisiensi pajak penghasilan badan pada PT Abdya Gasindo

\section{TINJAUAN PUSTAKA}

\section{Pajak}

\section{A. Definisi Pajak}

Pajak sebagai salah satu sumber pendapatan utama yang diperoleh dari sumber dana dalam negeri, merupakan iuran rakyat untuk kas negara yang tidak mendapat balas jasa secara langsung dan digunakan dalam pembiayaan pembangunan Yang didasarkan pada undang-undang, sehingga dapat dipaksakan dengan tiada mendapat balas jasa secara langsung. Pajak dipungut penguasa berdasarkan norma-norma hukum untuk menutup biaya produksi barangbarang dan jasa kolektif untuk mencapai kesejahteraan umum.

B. Penghasilan yang termasuk Objek Pajak

Yang termasuk objek pajak penghasilan menurut UU Pajak Penghasilan No. 36 tahun 2008 pasal 4 ayat 1 , yaitu: 
a. Penggantian atau imbalan berkenaan dengan pekerjaan atau jasa yang diterima atau diperoleh termasuk gaji, upah, tunjangan, honorarium, komisi, bonus, grafikasi, uang pensiun, atau imbalan dalam bentuk lainnya, kecuali ditentukan lain dalam Undang-undang ini.

b. Hadiah dari undian atau pekerjaan atau kegiatan dan penghargaan.

c. Laba usaha.

d. Keuntungan karena penjualan atau karena pengalihan harta termasuk :

1. Keuntungan karena pengalihan harta kepada perseroan, persekutuan, dan badan lainnya sebagai penganti saham atau penyertaan modal.

2. Keuntungan yang diperoleh perseroan, persekutuan, dan badan lainnya karena pengalihan harta kepada pemegang saham, sekutu, atau anggota

3. Keuntungan karena likuidasi, penggabungan, peleburan, pemekaran, pemecahan, atau pengambilalihan usaha.

4. Keuntungan karena pengalihan harta berupa hibah, bantuan atau sumbangan, kecuali yang diberikan kepada keluarga sedarah dalam garis keturunan satu derajat, dan badan keagamaan atau badan pendidikan atau badan sosial atau pengusaha kecil termasuk koperasi yang ditetapkan oleh Menteri Keuangan, sepanjang tidak ada hubungannya dengan usaha, pekerjaan, pemilikan, atau penguasaan antara pihakpihak yang bersangkutan.

5. Keuntungan karena penjualan atau pengalihan sebagian atau seluruh hak penambangan, tanda turut serta dalam pembiayaan, atau permodalan dalam perusahaan pertambangan.

e. Penerimaan kembali pembayaran pajak yang telah dibebankan sebagai biaya dan pembayaran tambahan pengembalian pajak.

f. Bunga termasuk premium, diskonto, dan imbalan karena jaminan pengembalian hutang.

g. Dividen, dengan nama dan dalam bentuk apapun, termasuk dari dividen perusahaan asuransi kepada pemegang polis, dan pembagian sisa hasil usaha koperasi.

h. Royalty atau imbalan atas pengguanaan hak.

i. Sewa dan penghasilan sehubungan dengan penggunaan harta.

j. Penerimaan atau perolehan pembayaran berkala.

k. Keuntungan karena pembebasan hutang, kecuali sampai jumlah terlentu yang ditetapkan dengan Peraturan Pemerintah.

1. Keuntungan karena selisih kurs mata uang asing.

m. Selisih lebih karena penilaian kembali aktiva.

n. Premi asuransi.

o. Iuran yang diterima atau diperoleh perkumpulan dari anggotanya yang terdiri dari Wajib Pajak yang menjalankan usaha atau pekerjaan bebas.

p. Tambahan kekayaan neto yang berasal dari penghasilan yang belum dikenakan pajak.

q. Penghasilan dari usaha berbasis syariah.

r. Imbalan bunga sebagaimana dimaksud dalam undang-undang yang mengatur mengenai ketentuaan umum dan tata cara perpajakan.

s. Surplus Bank Indonesia.

D. Pajak Penghasilan Pasal 21

Pajak Penghasilan Pasal 21 merupakan pajak penghasilan $(\mathrm{PPh})$ yang dikenakan atas penghasilan berupa gaji, upah, honorarium, tunjangan, dan 
pembayaran lain dengan nama apapun sehubungan dengan pekerjaan, jasa, atau kegiatan yang dilakukan oleh wajib pajak orang pribadi dalam negeri.

$\mathrm{PPh}$ pasal 21 dipotong, disetor, dan dilaporkan oleh pemotong pajak, yaitu pemberi kerja, bendaharawan pemerintah, dana pensiun, badan, perusahaan, dan Penyelenggara kegiatan.

J. Penghasilan Tidak Kena Pajak (PTKP)

Menurut Peraturan Menteri Keuangan RI Nomor 101/PMK.010/2016 tentang Penghasilan

Tidak Kena Pajak (PTKP) adalah:

a. Untuk diri Wajib Pajak (WP) Rp 54.000.000,- per tahun.

b. Tambahan untuk Wajib Pajak yang kawin Rp 4.500.000,- per tahun.

c. Tambahan untuk istri yang penghasilannya digabung dengan penghasilan suami $\mathrm{Rp}$ $54.000 .000,-$ per tahun. d. Tambahan untuk setiap anggota sedarah dalam garis keturunan lurus, serta anak angkat yang menjadi tanggungan sepenuhnya, paling banyak 3(tiga) orang Rp 4.500.000,- per tahun. oleh Wajib Pajak.

\section{K . Tarif Pajak \\ 1. Tarif Tetap}

Tarif pajak yang jumlahnya tetap walaupun dasar pengenaan pajaknya berbeda sehingga jumlah pajak yang terhutang selalu tetap. Contohnya adalah bea materai.

\section{Tarif Progresif}

Tarif pajak yang presentasenya semakin besar jika dasar pengenaan pajaknya meningkat. Contohnya adalah Tarif Pajak atas Penghasilan Kena Pajak (PKP) Wajib Pajak orang pribadi dalam negeri sesuai dengan Undang-Undang PPh Nomor 36 Pasal 17 Tahun 2008, yaitu sebagai berikut:

a. Untuk wajib pajak orang pribadi dalam negeri

Tabel 1. Daftar tarif pajak penghasilan wajib pajak orang pribadi

\begin{tabular}{|l|c|}
\hline \multicolumn{1}{|c|}{ Penghasilan Kena Pajak } & Tarif Pajak \\
\hline Sampai dengan Rp. 50.000.000 & $5 \%$ \\
\hline Di atas Rp. 50.000.000 s.d. Rp. 250.000.000 & $15 \%$ \\
\hline Di atas Rp. 250.000.000 s.d Rp. 500.000.000 & $25 \%$ \\
\hline Di atas Rp. 500.000.000 & $30 \%$ \\
\hline
\end{tabular}

b. Untuk Wajib Pajak Badandalam negeri dan BUT (Badan Usaha Tetap) Tarif pajak untuk Wajib Pajak badan dalam negeri dan bentuk usaha tetap (BUT) sebesar 28\% (dua puluh delapan persen). Tarif $\mathrm{PPh}$ tersebut menjadi $25 \%$ (dua puluh lima persen) mulai berlaku tahun pajak 2010. Wajib Pajak badan dalam negeri yang berbentuk perseroan terbuka yang paling sedikit $40 \%$ (empat puluh persen) dari jumlah keseluruhan saham yang disetor diperdagangkan dibursa efek di Indonesia dan memenuhi persyaratan tertentu lainnya dapat memperoleh tarif sebesar 5\% (lima persen) lebih rendah dari pada tarif 
sebagaimana di maksud pada ayat (1) huruf $b$ dan ayat (2) huruf a yang di atur dengan atau berdasarkan Peraturan Pemerintah.

Perhitungan $\mathrm{PPh}$ terutang berdasarkan pasal $31 \mathrm{E}$ dapat dibedakan menjadi 2 yaitu:

1. Jika peredaran bruto sampai dengan 4,8 miliar , maka perhitungan $\mathrm{PPh}$ nya sebagai berikut :

$\mathrm{PPh}$ terutang $=50 \% \times 25 \% \times$ seluruh Penghasilan Kena Pajak

2. Jika peredaran bruto lebih dari 4,8 miliar atau sampai dengan 50 milliar, maka perhitungan PPh terutang yaitu sebagai berikut : PPh terutang $=(50 \% \times 25 \%)$ Penghasilan Kena Pajak dari bagian peredaran bruto yang memperoleh fasilitas $+25 \%$ x Penghasilan Kena Pajak dari bagian peredaran bruto yang tidak memperoleh fasilitas. Perhitungan Penghasilan Kena Pajak dari bagian peredaran bruto yang memperoleh fasilitas yaitu : (Rp. 4.800.000.000/ peredaran bruto ) x Penghasilan Kena Pajak. Perhitungan Penghasilan Kena Pajak dari peredaran bruto yang tidak memperoleh fasilitas yaitu : Penghasilan Kena Pajak - Penghasilan Kena Pajak dari bagian peredaran bruto yang memperoleh fasilitas. Perhitungan Penghasilan Kena Pajak dari bagian peredaran bruto yang tidak memperoleh fasilitas yaitu Penghasilan Kena Pajak - Penghasilan Kena Pajak dari bagian peredaran bruto yang memperoleh fasilitas. Namun mulai tahun 2010, tarif PPh Badan adalah 25\% dari penghasilan bruto.

\section{Tax Planning}

Menurut Chairil (2013), Tax Planning adalah adalah suatu proses mengorganisasi usaha wajib pajak sedemikian rupa agar utang pajaknya baik pajak penghasilan maupun pajak lainnya berada dalam jumlah minimal, selama hal tersebut tidak melanggar ketentuan undang-undang. Dalam Prianto (2016), Perencanaan Pajak didefinisikan sebagai suatu proses untuk merekayasa usaha dan transaksi Wajib Pajak supaya utang pajak berada dalam jumlah yang minimal tetapi masih dalam bingkai peraturan perpajakan. Perencanaan pajak dapat berkonotasi positif sebagai perencanaan pemenuhan kewajiban perpajakan secara lengkap, benar, dan tepat waktu sehingga dapat menghindari pemborosan sumber daya secara optimal.

Dalam Tax Planning ada 3 macam cara yang dapat dilakukan wajib pajak untuk menekan jumlah beban pajaknya, yakni:

1.. Tax Avoidance (Penghindaran Pajak)

2.Tax Evasion

3. Tax Saving

Contoh: Bila kita belanja the botol di warung, tentu tidak aka nada pengenaan pajak restoran atas konsumsi tersebut, namun bila kita memesan the botol di hotel atau restoran besar, kita akan terbebani pajak restoran (yang sebenarnya bisa dihindari) sebagi implikasi perpajakannya (Chairil:2013).

a. Tujuan Penerapan Perencanaan Pajak (Tax Planning)

Secara umum tujuan pokok yang ingin dicapai dari perencanaan pajak yang baik adalah (Chairil:2013):

1. Meminimalisasi beban pajak yang terutang. Tindakan yang harus diambil dalam rangka perencanaan pajak tersebut berupa usaha-usaha mengefisiensikan beban pajak yang masih dalam 
ruang lingkup pemajakan dan tidak melanggar peraturan perpajakan.

2. Memaksimalkan laba setelah pajak

3. Meminimalkan terjadinya kejutan pajak (Tax Surprise) jika terjadi pemeriksaan pajak oleh fiskus.

4. Memenuhi kewajiban perpajakannya secara benar, efisien, dan efektif sesuai dengan ketentuan perpajakan yang antara lain meliputi:

a) Mematuhi segala ketentuan administratif, sehingga terhindar dari pengenaan sanksi, baik sanksi administratif maupun pidana, seperti bunga, kenaikan, denda, dan hukum kurungan atau penjara.

b) Melaksanakan secara efektif segala ketentuan undang-undang perpajakan yang terkait dengan pelaksanaan pemasaran, pembelian, dan fungsi keuangan, seperti pemotongan dan pemungutan pajak $(\mathrm{PPh}$ Pasal 21, Pasal 22, dan Pasal 23)

b. Strategi Umum Perencanaan Pajak

Menurut Chairil:2013, Strategi Pajak yang dapat ditempuh untuk mengefisiensikan beban pajak secara legal yaitu:

1.Tax Saving

2.Tax Avoidance

c. Perencanaan Pajak Penghasilan Badan

Menurut Chairil:2013, menyusun perencanaan pajak PPh Badan tidak bisa berjalan sendiri tanpa memfaktorkan jenis-jenis pajak lainnya, karena perhitungan PPh Badan memiliki keterkaitan atau interpendensi dengan $\mathrm{PPh}$ pasal 21, PPh pasal 22, $\mathrm{PPh}$ pasal 23/26, $\mathrm{PPh}$ final dan juga PPN. Keterkaitan tersebut adalah sebagai berikut:

a. Total omset penjulan dalam SPT PPh badan harus sama dengan total omset penjualan yang ada dalam akumulasi SPT Masa PPN pada akhir tahun pajak, jika berbeda perlu dilakukan equalisasi atau rekonsiliasi.

b. Ketika perusahaan memilih apakah menerapkan metode net, gross, atau gross up pada saat menghitung PPh pasal 21, keputusan ini akan berpengaruh pada besarnya PPh badan.

c. Pengeluaran biaya gaji upah, honorarium, dan sebagainya yang menyangkut kesejahteraan karyawan yang tercantum dalam SPT PPh badan harus sama dengan Dasar Pengenaan Pajak PPh pasal 21 berupa penghasilan bruto yang dibayarkan pada karyawan, jika berbeda perlu dilakukan equalisasi atau rekonsiliasi.

d. Pemberian dalam bentuk natura tidak diperkenankan sebagai biaya fiskal kecuali yang ditetapkan dalam PMK No. 82/PMK.03/2011.

e. Dalam laporan keuangan/neraca terdapat Pajak Penghasilan Pasal 22/23/26 yang menjadi dasar penghitungan $\mathrm{PPh}$ badan terhutang. Apabila pendapatan perusahaan sudah dikenakan $\mathrm{PPh}$ final, tidak dihitung lagi sebagai penghasilan kena pajak yang terhutang PPh badan.

d. Perencanaan Pajak Penghasilan Pasal 21

Menurut Omposunggu (2011) Perencanaan pajak bagi perusahaan pemberi kerja sebagai berikut:

a. Menerapkan prinsip taxable dan deductable yaitu dengan:

1. Menerapkan biaya non deductable menjadi deductable.

2. Mengubah penghasilan merupakan objek pajak menjadi penghasilan bukan objek pajak.

b. Memaksimalkan biaya karyawan yang dapat dialokasikan sebagai biaya usaha atau biaya fiskal. 
c. Mengalihkan pemberian natura menjadi bentuk uang sehingga deductability.

e. Manfaat Perencanaan Pajak

Ada beberapa manfaat yang bisa diperoleh dari perencanaan pajak yang dilakukan secara cermat:

1. Penghematan Kas Keluar, karena beban pajak yang merupakan unsur biaya dapat dikurangi

2. Mengatur aliran kas masuk dan keluar (Cash Flow), karena dengan perencanaan pajak yang matang dapat diperkirakan kebutuhan kas untuk pajak, dan menentukan saat pembayaran sehingga perusahaan dapat menyusun anggaran kas secara lebih akurat.

\section{- $\quad$ Efisiensi}

Dalam pengertian yang umum, suatu perusahaan yang efisien adalah suatu perusahaan yang dalam produksinya menghasilkan barang atau jasa dengan cepat dan lancar dengan pemborosan ynag minimum

\section{METODE PENELITIAN}

\section{A. Pendekatan Penelitian}

Penelitian ini menggunakan jenis penelitian deskriptif kuantitatif dengan menggunakan pendekatan Studi Kasus. Sugiyono (2013), mendefinisikan "Penelitian deskriptif adalah metode yang digunakan untuk menggambarkan atau menganalisis suatu hasil penelitian tetapi tidak digunakan untuk membuat kesimpulan yang lebih luas”. Dalam penelitian studi kasus ini tidak sampai mempermasalahkan hubungan antara variablevariabel yang ada, dan juga tidak dimaksudkan untuk menarik suatu generalisasi yang menjelaskan variabel yang menyebabkan suatu gejala atau kenyataan sosial.

\section{Jenis dan Sumber Data}

\section{Jenis dan Sumber Data}

Data yang digunakan dalam penelitian ini adalah data sekunder. Data sekunder menurut Sugiyono (2013) merupakan sumber data penelitian yang diperoleh peneliti secara tidak langsung melalui media perantara (diperoleh dan dicatat oleh pihak lain). Data sekunder berasal dari data yang diperoleh dari konsultan pajak tempat dimana perusahaan melakukan konsultasi perpajakannya. Data yang digunakan berupa Laporan keuangan tahun 2018 (komersil dan fiskal), laporan perpajakan selama 2018, dan bukti pendukung lainnya.

\section{E. Teknik Pengumpulan Data.}

Teknik yang digunakan dalam pengumpulan data yang dibutuhkan dalam penelitian ini yaitu :

1. Dokumentasi, yaitu mengumpulkan data berupa dokumen dan catatan perusahaan yang diperlukan dalam penelitian ini.

2. Studi Kepustakaan, yaitu mengambil beberapa buku bacaan atau literatur sebagai bahan acuan masalah dan memperoleh landasan teori mengenai tax planning dan implementasinya melalui literatu-literatur, laporan, makalah, jurnal-jurnal, dan berbagai artikel yang berhubungan dengan permasalahan yang ada serta berguna bagi penyusunan hasil penelitian ini.

\section{F.Teknik Analisis Data.}

Statistik deskriptif digunakan untuk menganalisa data dengan cara mendeskriptifkan atau menggambarkan data yang telah terkumpul sebagaimana adanya tanpa bermaksud membuat kesimpulan yang berlaku umum atau generalisasi. 


\section{HASIL PENELITIAN DAN PEMBAHASAN}

\section{A. Hasil Penelitian.}

Tax Planning yang di lakukan oleh PT. Abdya Gasindo dalam meminimalkan beban pajak penghasilannya yaitu dengan memaksimalkan biaya fiskal. Dimana anggaran untuk membayar pajak penghasilan dapat dikurangi dengan mengeluarkan biaya yang bermanfaat bagi perusahaan dan karyawannya, hal ini dapat dilihat dari laporan laba rugi perusahaan.

Laporan laba rugi yang di sajikan oleh PT. Abdya Gasindo telah sesuai dengan standar akuntansi keuangan dan dengan jelas menggambarkan akunakun yang ada dengan nominalnya. Berikut ini adalah laporan laba rugi perusahaan untuk tahun 2018.

Tabel 2 LaporanLaba (Rugi) PT. Abdya Gasindo

Per 31 Desember Tahun 2018

\begin{tabular}{|l|r|r|r|}
\hline Keterangan & \multicolumn{1}{|l|}{ Komersil } & \multicolumn{1}{l|}{ Koreksi Fiskal } & \multicolumn{1}{l|}{ Fiskal } \\
\hline Penjualan bersih & 195.000 .000 & 195.000 .000 \\
\hline Beban pokok penjualan & 52.000 .000 & 52.000 .000 \\
\hline Laba Kotor & $\mathbf{1 4 3 . 0 0 0 . 0 0 0}$ & $\mathbf{1 4 3 . 0 0 0 . 0 0 0}$ \\
\hline Pendapatan lain-lain & 10.000 .000 & 10.000 .000 \\
\hline Beban penjualan & 14.000 .000 & 14.000 .000 \\
\hline Beban umum \& adm & 13.000 .000 & 13.000 .000 \\
\hline Beban Keuangan & 17.000 .000 & 17.000 .000 \\
\hline Beban lain-lain & 3.500 .000 & & 3.500 .000 \\
\hline Total biaya operasi & $\mathbf{4 7 . 5 0 0 . 0 0 0}$ & & $\mathbf{4 7 . 5 0 0 . 0 0 0}$ \\
\hline Laba sebelum pajak & $\mathbf{1 0 5 . 5 0 0 . 0 0 0}$ & & $\mathbf{1 0 5 . 5 0 0 . 0 0 0}$ \\
\hline
\end{tabular}

Sumber :Laporan Laba Rugi PT. Abdya Gasindo

Dari laporan laba rugi pada tabel 2 dapat di hitung biaya pajak terutang PT. Abdya Gasindo Sebagai berikut:

\begin{tabular}{|l|r|}
\hline Laba Fiskal & 105.500 .000 \\
\hline Tarif PPh & 2.500 .000 \\
\hline $5 \%$ x Rp. 50.000.000 & 8.325 .000 \\
\hline $15 \%$ x Rp. 55.500.000 & 10.825 .000 \\
\hline PPh terutang & 10.825 .000 \\
\hline Laba Setelah Pajak & 100 \\
\hline
\end{tabular}


Dari perhitungan sebelum penerapan Tax Planning, pajak penghasilan terutang yang harus di bayarkan oleh perusahaan adalah sebesar Rp.10.825.000. Dalam menerapkan Tax Planning, perusahaan terlebih dahulu harus memikirkan dengan matang sasaran dan tindakan yang tepat dalam melakukan Tax Planning tersebut.

Dari laporan keuangan yang telah disajikan ada hal tertentu yang dapat dilakukan oleh perusahaan untuk mengefisiensi pajak terutang yaitu :

1. Salah satu pengeluran yang dilakukan oleh PT. Abdya Gasindo yang di perkenankan oleh undang-undang perpajakan adalah melakukan pendidikan dan pengembangan SDM Sebesar Rp.12.000.000, selain memperoleh manfaat penurunan hutang pajak pada waktu tersebut juga PT. Abdya Gasindo dapat meningkatkan keahlian kerja para karyawan di masa yang akan datang. Manfaat perusahaan di kedepanya dimana sangat menguntungkan perusahaan karena dengan hal tersebut perusahaan semakin mampu bersaing dengan perusahaan lainya.

2. Biaya selanjutnya yang dapat dimanfaatkan oleh PT. Abdya Gasindo dalam pelaksanaan Tax Planning adalah Biaya pembelian telepon seluler dan pengisian pulsa terkait jabatan pekerjaan. Selain dapat mengurangi beban pajak diharapkan dengan komunikasi yang baik kegiatan

Dari perhitungan sebelum penerapan Tax Planning, pajak penghasilan terutang yang harus di bayarkan oleh perusahaan adalah sebesar Rp. 10.825.000 hal itu cukup besar oleh karena itu perlu adanya Tax Planning dalam rangka meminimalkan beban pajak yang ditanggung oleh perusahaan. Adapun langkah yang diambil perusahaan adalah operasional perusahan dapat berjalan dengan lancar.

Setelah menerapkan tax planning pada PT. Abdya Gasindo, maka setelah itu dilakukan evaluasi untuk melihat sejauh mana hasil pelaksanaan Tax Planning terhadap biaya yang di keluarkan oleh PT. Abdya Gasindo yang terkait dengan biaya pendidikan dan pengembangan SDM dan biaya pembelian telepon selular dan pengisian pulsa.

\section{Pembahasan}

a. Laporan Laba Rugi PT. Abdya Gasindo Sebelum Penerapan Tax Planning

Dalam meminimalkan beban pajak penghasilannya PT. Abdya Gasindo memanfaatkan biaya yang dapat mengurangi beban pajak yang sesuai dengan peraturan undang-undang No. 36 Tahun 2008 tentang pajak pennghasilan.

Dari laporan laba rugi pada table 3 dapat di hitung biaya pajak PT. Abdya Gasindo sebelum dilaksanakan Tax Planning, sebagai berikut :

\begin{tabular}{|l|l|}
\hline Laba Fiskal & 105.500 .000 \\
\hline Tarif PPh & \\
\hline $5 \%$ x Rp. 50.000 .000 & 2.500 .000 \\
\hline $15 \%$ x Rp. 55.500.000 & 8.325 .000 \\
\hline PPh terutang & 10.825 .000 \\
\hline Laba Setelah Pajak & 10.825 .000 \\
\hline
\end{tabular}

dengan meminimalkan anggaran untuk membayar beban pajak dengan mengeluarkan biaya yang bermanfaat bagi karyawan dan perusahaan. Adapun Tax Planning yang dilakukan oleh PT. Abdya Gasindo yaitu dengan mengeluarkan biaya pendidikan dan pelatihan SDM serta biaya pembelian telepon seluler dan pengisian pulsa. 
Tabel 3

Laporan Laba (Rugi) PT. Abdya Gasindo sebelum Tax Planning Per 31 Desember Tahun 2018

\begin{tabular}{|l|r|r|r|}
\hline \multicolumn{1}{|c|}{ Keterangan } & \multicolumn{1}{c|}{ Komersil } & \multicolumn{1}{c|}{ Koreksi Fiskal } & \multicolumn{1}{c|}{ Fiskal } \\
\hline Penjualan bersih & 195.000 .000 & & 195.000 .000 \\
\hline Beban pokok penjualan & 52.000 .000 & & 52.000 .000 \\
\hline Laba Kotor & $\mathbf{1 4 3 . 0 0 0 . 0 0 0}$ & & $\mathbf{1 4 3 . 0 0 0 . 0 0 0}$ \\
\hline Pendapatan lain-lain & 10.000 .000 & & 10.000 .000 \\
\hline Beban penjualan & 14.000 .000 & & 14.000 .000 \\
\hline Beban umum \& adm & 13.000 .000 & & 13.000 .000 \\
\hline Beban Keuangan & 17.000 .000 & & 17.000 .000 \\
\hline Beban lain-lain & 3.500 .000 & & 3.500 .000 \\
\hline Total biaya operasi & $\mathbf{4 7 . 5 0 0 . 0 0 0}$ & & $\mathbf{4 7 . 5 0 0 . 0 0 0}$ \\
\hline Laba sebelum pajak & $\mathbf{1 0 5 . 5 0 0 . 0 0 0}$ & & $\mathbf{1 0 5 . 5 0 0 . 0 0 0}$ \\
\hline
\end{tabular}

Sumber : Laporan Laba Rugi PT. Abdya Gasindo

\section{b. Penerapan Tax Planning Sesuai Dengan Undang}

- Undang No 36 Tentang Pajak Penghasilan Pasal 6 terkait Biaya yang boleh dikurangkan Sebagai Pengurang Beban Pajak Penghasilan

Laporan keuangan yang di susun oleh PT. Abdya Gasindo merupakan gambaran proses usaha, baik mengenai perkembangan kemajuan perusahaan serta hambatan-hambatan saat beroperasinya perusahaan. Data dan laporan tersebut yang akan digunakan sebagai pertimbangan dan evaluasi dalam mengambil langkah-langkah usaha selanjutnya yang mengarah pada perkembangan serta kemajuan perusahaan tersebut. Adapun data dan laporan yang berhubungan dengan skripsi ini adalah laporan laba rugi tahun 2018. Untuk pencapaian rencana tersebut maka dilakukan efisiensi PPh Badan dengan cara yang legal untuk memperkecil beban pajak dari suatu badan usaha.

Berikut adalah analisis dari penerapan tax planning PT Abdya Gasindo terhadap jumlah penghasilan terutang yang dibandingkan sebelum melakukan tax planning dan sesudah melakukan Tax Planning.

\section{a. Pendidikan dan Pengembangan SDM}

PT. Abdya Gasindo mengeluarkan biaya pendidikan dan pelatihan sumber daya manusia sebagai salah satu pengeluaran yang diperkenankan Undang-undang perpajakan. Selain untuk memperoleh manfaat penurunan hutang pajak juga untuk lebih mengembangkan sumber daya manusia agar lebih terampil dan lebih berwawasan dalam bekerja. 
Tabel 4

Penerapan Tax Planning untuk biaya pendidikan dan pelatihan sumber daya manusia

\begin{tabular}{|l|r|r|r|}
\hline \multicolumn{1}{|c|}{ Keterangan } & \multicolumn{1}{c|}{ Komersil } & \multicolumn{1}{c|}{ Koreksi Fiskal } & \multicolumn{1}{c|}{ Fiskal } \\
\hline Penjualan bersih & 195.000 .000 & & 195.000 .000 \\
\hline Beban pokok penjualan & 52.000 .000 & & 52.000 .000 \\
\hline Laba Kotor & $\mathbf{1 4 3 . 0 0 0 . 0 0 0}$ & & $\mathbf{1 4 3 . 0 0 0 . 0 0 0}$ \\
\hline Pendapatan lain-lain & 10.000 .000 & & 10.000 .000 \\
\hline Beban penjualan & 14.000 .000 & & 14.000 .000 \\
\hline Beban umum \& adm & 13.000 .000 & & 13.000 .000 \\
\hline Beban Keuangan & 17.000 .000 & & 5.000 .000 \\
\hline Biaya pendidikan dan pelatihan SDM & 5.000 .000 & & 3.500 .000 \\
\hline Beban lain-lain & 3.500 .000 & & $\mathbf{4 7 . 5 0 0 . 0 0 0}$ \\
\hline Total biaya operasi & $\mathbf{4 7 . 5 0 0 . 0 0 0}$ & & $\mathbf{1 0 5 . 5 0 0 . 0 0 0}$ \\
\hline Laba sebelum pajak & $\mathbf{1 0 5 . 5 0 0 . 0 0 0}$ & & \\
\hline
\end{tabular}

Perhitungan pada tabel 4 menyangkut pajak penghasilan terutang untuk biaya pendidikan dan pelatihan SDM adalah sebagai berikut :

\begin{tabular}{|l|r|}
\hline Laba Fiskal & 100.500 .000 \\
\hline Tarif PPh & 2.500 .000 \\
\hline 5\% x Rp. 50.000.000 & 7.575 .000 \\
\hline 15\% xp. 50.500 .000 & 10.075 .000 \\
\hline PPh terutang & \\
\hline Laba Setelah Pajak & \\
\hline \multicolumn{1}{|c|}{ Apabila P T. Abdy a Gasindo tidak } & 10.075 .000 . \\
\hline
\end{tabular}

melakukan pengeluaran biaya pendidikan dan pelatihan SDM maka total pajak penghasilan yang harus dibayarkan adalah sebesar Rp10.825.000 . Dengan Tax Planning perusahaan dapat mengeluarkan biaya pendidikan dan pelatihan SDM sehingga perusahaan dapat menurunkan total pajak penghasilannya sebesar Rp 10.075.000. Sehingga perusahaan dapat menghemat pengeluaran pajak penghasilan terutang sebesar Rp

\section{b. Biaya Pembelian Telepon seluler dan Pulsa}

Biaya pembelian telepon seluler dan pengisian pulsa sebesar Rp 4.000.000 di mana yang diberikan kepada Penjaga Toko, Supir, Admin kantor. Dimana diharapkan kinerja dapat lebih terkordinasi menjadi lebih baik melalui komunikasi yang baik pula. Bedasarkan keputusan Dirjen Pajak (KEP) No. 220/PJ/2002 biaya pembelian telepon 
selular dan pengisian pulsa terkait dengan jabatan dan pekerjaan dapat dijadikan sebagai beban fiskal hanya sebesar 50\% saja dari keseluruhan beban yang dikeluarkan. Jadi beban yang dikelurkan berupa biaya pembelian telepon selular dan pengisian pulsa terkait dengan jabatan dan pekerjaan dikoreksi fiskal positif dalam laporan Laba Rugi.

Tabel 5

Laporan Laba Rugi PenerapanTax Planning untuk Biaya pembelian telepon dan Pulsa

\begin{tabular}{|l|r|r|r|}
\hline \multicolumn{1}{|c|}{ Keterangan } & \multicolumn{1}{|c|}{ Komersil } & \multicolumn{1}{|c|}{ Koreksi Fiskal } & \multicolumn{1}{c|}{ Fiskal } \\
\hline Penjualan bersih & 195.000 .000 & & 52.000 .000 \\
\hline Beban pokok penjualan & 52.000 .000 & $\mathbf{1 4 3 . 0 0 0 . 0 0 0}$ & $\mathbf{1 4 3 . 0 0 0 . 0 0 0}$ \\
\hline Laba Kotor & 10.000 .000 & 10.000 .000 \\
\hline Pendapatan lain-lain & 14.000 .000 & 14.000 .000 \\
\hline Beban penjualan & 13.000 .000 & 13.000 .000 \\
\hline Beban umum \& adm & 17.000 .000 & & 17.000 .000 \\
\hline Beban Keuangan & 4.000 .000 & 2.000 .000 & 2.000 .000 \\
\hline Biaya telepon selular dan pulsa & 3.500 .000 & & 3.500 .000 \\
\hline Beban lain-lain & $\mathbf{5 1 . 5 0 0 . 0 0 0}$ & $\mathbf{4 9 . 5 0 0 . 0 0 0}$ \\
\hline Total biaya operasi & $\mathbf{1 0 1 . 5 0 0 . 0 0 0}$ & & $\mathbf{1 0 3 . 5 0 0 . 0 0 0}$ \\
\hline Laba sebelum pajak & & & 1900 \\
\hline
\end{tabular}

Perhitungan terkait tabel 5 untuk pembelian telepon dan pulsa adalahsebagai berikut:

\begin{tabular}{|l|r|}
\hline Laba Fiskal & 103.500 .000 \\
\hline Tarif PPh & 2.500 .000 \\
\hline $5 \%$ x Rp. 50.000.000 & 8.025 .000 \\
\hline $15 \%$ x Rp. 53.500.000 & 10.525 .000 \\
\hline PPh terutang & 92.975 .000 \\
\hline Laba Setelah Pajak & 9 \\
\hline
\end{tabular}

Apabila PT. Abdya Gasindo tidak mengeluarkan biaya telepon dan pulsa, total pajak yang harus di bayar sebesar Rp. 10.825.000. Dengan Tax Planning perusahaan dapat mengeluarkan biaya telepon dan pulsa sehingga perusahaan dapat menurunkan total pajak penghasilan sebesar Rp. 10.525 .000 sehingga perusahaan dapat menghemat pajak sebesar Rp. 300.000, diperoleh dari Rp. 10.825.000 - 10.525.000) c. Laporan Laba Rugi CV Jaya Sentosa Setelah Penerapan Tax Planning

Sebelum melakukan Tax Planning total pajak penghasilan yang harus di bayar oleh PT. Abdya Gasindo apabila tidak melakukkan pendidikan dan pengembangan SDM serta Biaya pembelian telepon dan pulsa sebesar Rp. 10.825.000. Dengan melakukan Tax Planning perusahaan dapat mengeluarkan biaya pendidikan dan pelatihan SDM sebesar Rp. 750.000 dan mengadakan biaya 
Tabel 6

Laporan (Rugi) PT. Abdya Gasindo setelah Tax Planning

Per 31 DesemberTahun 2018

\begin{tabular}{|l|r|r|r|}
\hline Keterangan & Komersil & Koreksi Fiskal & Fiskal \\
\hline Penjualan bersih & 195.000 .000 & & 195.000 .000 \\
\hline Beban pokok penjualan & 52.000 .000 & & 52.000 .000 \\
\hline Laba Kotor & $\mathbf{1 4 3 0 . 0 0 . 0 0 0}$ & & $\mathbf{1 4 3 . 0 0 0 . 0 0 0}$ \\
\hline Pendapatan lain-lain & 10.000 .000 & & 10.000 .000 \\
\hline Beban penjualan & 14.000 .000 & & 14.000 .000 \\
\hline Beban umum \& adm & 13.000 .000 & & 13.000 .000 \\
\hline Beban Keuangan & 17.000 .000 & & 17.000 .000 \\
\hline Biaya pendidikan dan pelatihan SDM & 5.000 .000 & & 5.000 .000 \\
\hline Biaya telepon selular dan pulsa & 4.000 .000 & 2.000 .000 & 2.000 .000 \\
\hline Beban lain-lain & 3500000 & & 3500000 \\
\hline Total biaya operasi & $\mathbf{5 6 . 5 0 0 . 0 0 0}$ & & $\mathbf{5 4 . 5 0 0 . 0 0 0}$ \\
\hline Laba sebelum pajak & $\mathbf{9 6 . 5 0 0 . 0 0 0}$ & & $\mathbf{9 8 . 5 0 0 . 0 0 0}$ \\
\hline
\end{tabular}

Dari Laporan Laba Rugi pada table 5 dapat dihitung biaya pajak terutang PT. Abdya Gasindo setelah dilaksanakan Tax Planning sebagai berikut :

\begin{tabular}{|l|l|}
\hline Laba Fiskal & 98.500 .000 \\
\hline Tarif PPh & \\
\hline
\end{tabular}

Total pajak penghasilan yang harus di bayar oleh PT.Abdya Gasindo adalah yang dapat dilihat pada penyajian perhitungan pajak penghasilan terutang setelah penerapan kebijakan tax planning sehingga PT.Abdya Gasindo dapat melakukan penghematan pajak sebesar Rp.

10.825.000 - Rp 9.775.000 = Rp. 1.050.000,

hal ini sangat bermanfaat untuk penganggaran dana yang digunakan untuk kemajuan perusahaan kedepannya.

\begin{tabular}{|l|l|}
\hline $5 \%$ x Rp. 50.000.000 & 2.500 .000 \\
\hline $15 \%$ x Rp. 58.500.000 & 7.275 .000 \\
\hline PPh terutang & 9.775 .000 \\
\hline Laba Setelah Pajak & 88.725 .000 \\
\hline
\end{tabular}

Dari perhitungan diatas dapat jelas terlihat bahwa jumlah pajak penghasilan terutang berbeda dari sebelum tax planning sebesar Rp. 10.825.000 dan setelah dilakukan tax planning sebesar Rp. 9.775.000 efisiensi yang di dapat dari perencanaan tersebut dengan memanfaatkan peraturan perundang undangan pajak penghasilan No 36 tahun 2008 adalah sebesar

Rp.1.050.000.

Dimana 


\section{KESIMPULAN DAN SARAN}

\section{Kesimpulan.}

Berdasarkan penelitian yang sudah dilakukan dan pembahasan terhadap penelitian tersebut sudah diuraikan secara detail, maka dapat diambil kesimpulan bahwa:

1. Penerapan kebijakan Tax Planning pada PT. Abdya Gasindo bertujuan untuk mengolah kewajiban perpajakan secara lengkap dan benar . Sedangkan apabila diterapkan dengan benar kebijakan tax planning ini dapat diperoleh manfaat adalah dapat meminimalisasi beban pajak sebagai unsur biaya sehingga dapat menghemat arus kas keluar.

2. Dari hasil perhitungan sebelum dan setelah tax planning terlihat jumlah pajak penghasilan yang terutang sangat bebeda sebelum tax planning dan setelah tax planning. Artinya ada penghematan pajak yang terjadi, dimana penghematan ini terjadi karena PT.Abdya Gasindo mengeluarkan biaya pendidikan dan pengembangan SDM serta biaya pembelian telepon dan pulsa. Dimana hal ini diperbolehkan dalam undang-undang no 36 tahun 2008 pasal 6 ayat 1 huruf $g$

3. PT. Abdya Gasindo adalah perusahaan yang taat dalam pembayaran perpajakannya karena terlihat dari tidak adanya sanksi ataupun denda dari pihak berwenang pajak.

\section{Saran}

Berdasarkan pada keterbatasan penelitian, maka direkomendasikan beberapa saran sebagai berikut :

1. Pemberian manfaat pendidikan dan pengembangan SDM menjadi alternative dalam efisiensi, hal ini di sebabkan adanya 2 (dua) keuntungan sekaligus yaitu berkurangnya beban pajak dan meningkatkan kualitas karyawan di masa yang akan datang.

2. P T Abdya Gasindo sebaiknya mengadakan pelatihan perpajakan secara khusus bagi karyawan staf administrasi hal ini agar bidang perpajakan dapat ditangani oleh orang yang tepat.

\section{DAFTAR PUSTAKA}

Nurjannah,2014, Implementasi Perencanaan Pajak (Tax Planning) Untuk Penghematan JumlahPajak Penghasilan PT Bosowa Maros, Skripsi, Universitas Hasanudin Makassar.

Windriarti, Maretha, 2012, Analisis Penerapan Perencanaan Pajak Penghasilan Badan PadaPT Semen Tonasa Di Pangkep, Skripsi, Universitas Hasanudin Makassar.

Silitonga, Laorens , 2013, Penerapan Tax Planning Atas Pajak Penghasilan Badan Pada CV Andi Offset Cabang Manado, Jurnal, Universitas Sam Ratulangi Manado.

Librata, Noviandi, 2009, Analisis Penerapan Tax Planning dalam Upaya Meningkatkan Efisiensi Pembayaran Beban Pajak Penghasilan pada PT. Graha Mitra Sukarami, Jurnal, STIE MDP.

Mahib, Ery Marlina, 2012, Perencanaan Pajak Sebagai Upaya Meminimalkan PPh Badan PadaPT. Matahari Yupha Perkasa, Skripsi, Universitas Wijaya Putra Surabaya..

Pernanda, Dian, 2008, Perencanaan Pajak dalam Rangka Penghematan Pembayaran PajakTerutang Studi Kasus pada PT. GL HITech Indonesia, Jurnal. 
Pohan, Chairil Anwar, 2013, Manajemen Perpajakan : Strategi Perencanaan Pajak dan Bisnis,Edisi Revisi, Cetakan Pertama, Gramedia, Jakarta.

Puspitasari, Indah Yulia, 2009, Penerapan Tax Planning atas Pajak Penghasilan (PPh) Badan(Studi Kasus Pada CV. Scronica Sari), Jurnal.

Rori,Handri, 2013, Analisis Penerapan Tax planning Atas Pajak Penghasilan Suandy, Erly, 2007, Perencanaan Pajak, Edisi 5, Salemba Empat, Jakarta. Suandy, Erly, 2013, Perencanaan Pajak, Edisi 6, Salemba Empat, Jakarta

Rumuy, Renita, 2013, Penerapan Perencanaan Pajak Penghasilan Badan Sebagai UpayaEfisiensi Pembayaran Pajak PT Sinar Sasongko, Jurnal,STIE MDP.

Mahib, Ery Marlina, 2012, Perencanaan Pajak Sebagai Upaya Meminimalkan PPh Badan Pada PT. Matahari Yupha Perkasa, Skripsi, Universitas Wijaya Putra Surabaya..

Pohan, Chairil Anwar, 2013, Manajemen Perpajakan : Strategi Perencanaan Pajak dan Bisnis, Edisi Revisi, Cetakan Pertama, Gramedia, Jakarta.

Puspitasari, Indah Yulia, 2009, Penerapan Tax Planning atas Pajak Penghasilan (PPh) Badan(Studi Kasus Pada CV. Scronica Sari), Jurnal.

Rori,Handri, 2013, Analisis Penerapan Tax planning Atas Pajak Penghasilan

Suandy, Erly, 2007, Perencanaan Pajak, Edisi 5, Salemba Empat, Jakarta. Suandy, Erly, 2013, Perencanaan Pajak, Edisi 6, Salemba Empat, Jakarta
Waluyo, 2012, Akuntansi Pajak, Salemba Empat, Jakarta. Waluyo. 2008. Perpajakan Indonesia. Salemba Empat, Jakarta.

Zain, M, 2005, Manajemen Perpajakan, Salemba Empat, Jakarta.

Wirawan B dan Rudi Suhartono, 2009, Pajak Penghasilan, Lembaga Penerbit Fakultas UI, Jakarta.

Mardiasmo, 2011. Perpajakan Edisi Revisi 2011, Penerbit Andi Yogyakarta.

Widyaningsih,2011. Hukum Pajak dan Perpajakan, Penerbit Alfabeta, Bandung.

Waluyo, 2012, Akuntansi Pajak, Salemba Empat, Jakarta. Waluyo. 2008. Perpajakan Indonesia. Salemba Empat, Jakarta.

Zain, M dan Diana Sari, 2006, Perpajakan Lanjutan, Salemba Empat, Jakarta. Zain, M, 2005, Manajemen Perpajakan, Salemba Empat, Jakarta.

Wirawan B dan Rudi Suhartono, 2009, Pajak Penghasilan, Lembaga Penerbit Fakultas UI, Jakarta.

Mardiasmo, 2011. Perpajakan Edisi Revisi 2011, Penerbit Andi Yogyakarta. Widyaningsih,2011. Hukum Pajak dan Perpajakan, Penerbit Alfabeta, Bandung. 
